\title{
Amory's Sexual Illusion in This Side of Paradise
}

\author{
Thi Huong Giang Bui \\ Department of English Literature, Fukuoka Women's University, Fukuoka, Japan
}

\begin{abstract}
The present paper deals with the sexual illusion of F. Scott Fitzgerald's male character, Amory Blaine, in This Side of Paradise. Based on the close study of psychoanalytic approach and Freud's works, the main concern of the study focuses on the changes of Amory's sexual desires in different phases of his life. Due to the loss of an idealized father figure, Amory strives to become a substitute father himself and falls into sexual illusion with different women. With the aim of bringing a new way of reading and analyzing This Side of Paradise, this paper attempts to investigate Amory's sexual illusion which derives from his unstable identity and loss in his life.
\end{abstract}

Index Terms-This Side of Paradise, psychoanalytic approach, Freud, illusion, sexual desire, trauma

\section{INTRODUCTION}

In the essay "History and Masculinity in F. Scott Fitzgerald's This Side of Paradise", Pearl James clarifies the meaning of gender and its ambiguity in early twentieth century American culture in general and in bildungsroman in particular. Historically viewed from the grounds of the essay, sexual identities are exemplified in cultural and social changes. Then he exhibits the idea of the cultural anxiety about the coherence of masculinity in the early twentieth century and shows how the anxiety exacerbated by World War I. Besides, James suggests that Fitzgerald, unlike nineteenth-century writers, shows that identity is performed and relatively unstable, because there has been a shift from "character" to "personality". James persuasively exhibits that the novel presents "masculinity as an unachievable ideal, complicated from without by contradictory cultural imperatives and from within by homoerotic desires, experiences of loss, and feelings of inadequacy" (James, 2005, p. 4). Furthermore, according to Linda C. Pelzer (2000), This Side of Paradise is "a novel about disillusionment and loss" (Pelzer, 2000, p. 44). Therefore, This Side of Paradise depicts the unstable identity and the sexual illusions of the central character, Amory Blaine, leading him to be a failure man in life.

Concerning to the notion of sexuality, Lois Tyson writes that "for some psychoanalytic theories, especially in the past, sexuality was a matter of a biological pressure that is discharged in the act of sexual intercourse" (Tyson, 2006, p. 24). By using the word sexuality, "Freud called that drive eros and placed it in opposition to thanatos, the death drive" (Tyson, 2006, p. 24). Furthermore, Freud "realized that our sexuality is part and parcel of our identity and thus relates to our capacity to feel pleasure in ways that are not generally considered sexual" (Tyson, 2006, p. 24). Based on the Freudian concept of sexuality "psychoanalysis today sees a close connection between our sexuality and our identity because the origin of our sexual being is in the nature of the affirmation or disruption of our sense of self that occurs in childhood" (Tyson, 2006, p. 24). Drawing from psychoanalytic approach, we can say that Amory's sexual illusion derives from his unstable identity and psychological loss of lacking the father's role in the early stage of his life and that makes him become a failure man throughout the novel. Linda C. Pelzer also points out that "expulsion from college and rejection by the woman he loves eventually lead Amory to discover that his dreams are not enough to ensure his desires, and he grows disillusioned with life" (Pelzer, 2000, p. 35). For that reason, the novel clearly shows Amory's downfall which has resulted from his sexual illusion through his life.

\section{DISCUSSION}

In This Side of Paradise, the narrator evidently points out that Amory is shaped by his unique mother, Beatrice O'Hara, from a very early age. Amory might seem to be separated from most other people, even his father. Amory's father, Stephen Blaine, plays a very dim role in Amory's life. According to Stavola, "Fitzgerald's portrait of Amory's father, Stephen Blaine, is sparse [and] fundamentally weak, his influence upon Amory is negligible and in the long run will cause much more psychological harm than good" (Stavola, 1979, p. 76). Evidently, "Fitzgerald's treatment of Amory's parents reflects an important shift in American parental authority, a shift with debilitating effects upon offspring" (Stavola, 1979, p. 76). In this American society, "the mother has assumed the place of dominance in the family, in education, and in cultural life [...] her power, a misplaced paternalism, is occasionally of great value in the training of the children; but more often it is crippling to the pursuit of identity and maturity" (Stavola, 1979, p. 76). This idea can be seen paralleled in This Side of Paradise in a surprisingly specific way. Although Beatrice has great influence on Amory's childhood without any instruction and moral guides of his father, Amory has "no illusion about her" (Fitzgerald, 2003, p. 12).

Drawing from the Freudian concept, Amory lacks of representative figure in his childhood and it causes Amory's illusion in his later life. It can be suggested that Amory is traumatized by the loss of the father in the early stage of his life. He grows up with the lack of love of his father. Amory only learns instructions from his mother which then shape 
his personalities. It is not difficult to see Beatrice's transference of her personalities and her characteristic to her son. Although Beatrice is seen as a dynamic and strong woman, her female troubles and nerves always follows and haunts Amory's childhood. As Stavola points out that "an aristocratic Victorian superficial educated in Europe near Lake Geneva, Beatrice is shallow, snobbish and extremely self-centered, except for her smothering love for her son [...] But beneath this tangled network of externals Beatrice is essentially insecure, mistrustful, and lacks a firm sense of identity" (Stavola, 1979, p. 77). Even Amory leaves Beatrice "to spend the ensuing two years with his aunt and uncle" (Fitzgerald, 2003, p.15), and then is sent to St. Regis', a boy's preparatory school, which can be supposed to instill his independence and masculinity. However, Anthony thinks that "St. Regis' spoiled him" (Fitzgerald, 2003, p. 39). Moreover, the intrusive narrator also suggests that "Amory plus Beatrice plus two years in Minneapolis-these had been his ingredients when he entered St. Regis'. But the Minneapolis years were not a thick enough overlay to conceal the "Amory plus Beatrice" from the ferreting eyes of a boarding school [...] But both St. Regis" and Amory were unconscious of the fact that this fundamental Amory had not in himself changed" (Fitzgerald, 2003, p. 37). So, "since Stephen Blaine is weak, passive, and often absent, Amory turns, as a child, towards his mother for a model imitate. Almost completely unawares he takes upon himself many of her key feminine traits which become the basis of his character" (Stavola, 1979, p. 77). Therefore, we can conclude that Amory's effeminacy is shaped and formed from his childhood due to much influence of his mother figure and lack of father's role.

Due to "the intense affections of a neurotic mother and the unattractiveness of a passive father" (Stavola, 1979, p. 79), Amory strives to fulfill his stable identity through the romantic relationship with a various girls in his later life as a means to "to achieve a firm identity and survive in a world not controlled by a strong mother figure" (Stavola, 1979, p. 77). Linda C. Pelzer suggests that “Amory's dream of greatness is linked to an ideal of beauty embodied in the women he loves [and] each of them also represents an aspect of Amory's own self, and thus, his pursuit of each underscores the nature of his quest" (Pelzer, 2000, p. 43). However, Amory can never escape from the fantasy world that Beatrice creates for him and falls into the sexual illusions through his life.

His first childlike relationship is with Myra St. Claire when Amory is only thirteen, and this romance can be regarded as a "clearly sexual side of this unresolved Oedipal conflict in Amory" (Stavola, 1979, p. 81). Amory tries to attract Myra by his wealth and charm and quickly wants to create the romantic moment with her. The scene that Amory kisses Myra depicts his obsession of the hidden romantic fantasy; Amory "leaned over quickly and kissed Myra's cheek. He had never kissed a girl before, and he tasted his lips curiously, as if he had munched some new fruit" (Fitzgerald, 2003, p. 21). The scene is somewhat ridiculous and exhibits Amory's desire to grasp the romantic moment as quickly as he can. However, once he achieves it, he wants to ruin it right after his first kiss "sudden revulsion seized Amory, disgust, loathing for the whole incident" (Fitzgerald, 2003, p. 21) and "he [Amory] desired frantically to be away, never to see Myra again, never to kiss anyone" (Fitzgerald, 2003, p. 21). As Stavola points out that "the psychoanalytic source of Amory's sexual disgust after kissing Myra is an Oedipal failure [as] his abnormal closeness and identification with his mother compels Amory to treat every female he gets close to as his mother" (Stavola, 1979, p. 83). That is the reason why Amory seems to be very egotistic of the ideal romantic moment and shows how he wants to achieve it and then quickly to destroy it. In fact, it is the time Amory begins to escape his childhood by distracting the influence of his mother and gaining the power in romantic affair. Moreover, he wants to cast the world around him and tries to jump and fit in the new world he is creating. However, it is evident that Amory can not achieve what he wants since he cannot escape himself from his childhood obsession.

Another romantic moment is repeated and ruined again when Amory is eighteen. This romance can be seen as "Amory's first real love" (Pelzer, 2000, p. 44) and "Isabelle embodies Amory's yearning for popularity and power" (Stavola, 1979, p. 90). During his vacation of sophomore year in Princeton, he falls in love with sixteen year old girl, Isabelle Borge. At this phase of life, Amory is still depicted as "an open subject" (Fitzgerald, 2003, p. 65), suggesting that nobody can understand him completely. As the third person narrator points out Amory is "evidently a bit light of love, neither popular nor unpopular - every girl there seemed to have had an affair with him at some time or other, but no one volunteered any really useful information" (Fitzgerald, 2003, p. 65).Like Myra, Amory quickly "was in love and his love was returned" (Fitzgerald, 2003: 88). Moreover, he supposes that "their love was to be eternal" (Fitzgerald, 2003 , p. 87). However, their romantic affair also quickly ends due to a very small incident. While Amory embraces Isabelle, his shirt-stud hurts her neck and leaves "a little blue spot" (Fitzgerald, 2003, p. 89). They quarrel incessantly for this and Isabelle accuses Amory of being egocentric, conceited and critical. Amory realizes that they actually do not love each other and leaves quickly. Later, Amory think "she [Isabelle] spoiled my year" (Fitzgerald, 2003, p. 93). Above all, Amory "wondered how much he cared - how much of his sudden unhappiness was hurt vanity-whether he was, after all, temperamentally unfitted for romance” (Fitzgerald, 2003, p. 92). A very small incident dooming Amory's romantic affair exhibits that Amory cannot identify his identity and has still keeps his naïve-self in his various romantic relationships. For Amory, Isabelle might seem like "a dream, a projection of Amory's imagination, and possessing her has convinced him of her insubstantiality” (Pelzer, 2000, p. 44). This romance once again depicts Amory's unstable identity in adapting himself in his life.

However, "Amory's disillusionment following his breakup with Isabelle is merely temporary; it does not deter him from pursuit of his ideal" (Pelzer, 2000, p. 44). Due to the failure of finding an idealized substitute figure, Amory, to some degree, strives to replace God [Darcy] and Devil [the ghostly Dick] to become a substitute father himself when he 
wants to marry Clara Page, his third cousin who has been widowed for six months, a woman who "was alone in the world, with two small children, little money, and, worst of all, a host of friends". Clara is also a woman whom Amory refers to as St. Cecelia. Obviously, Amory desires to become an exact idealized figure that haunts him all his life. It is a way to find his identity and his power. Another reason is Clara is "the first fine woman he ever knew and one of the few good people who ever interested him" (Fitzgerald, 2003, p. 133); therefore, Amory tries to prove that he becomes mature, personage and can be a model of Clara's children. Amory even begins "to speculate wildly on marriage" (Fitzgerald, 2003, p.133). However, Clara's "goodness was above the prosy morals of the husband-seeker" (Fitzgerald, 2003, p.131).

Although Amory falls in love with Clara and is eventually "jealous of everything about Clara: of her past, of her babies, of the men and women who flocked to drink deep of her cool kindness and rest their tired minds as at an absorbing play" (Fitzgerald, 2003, p.133), Clara just sees Amory as a "weak character" of "no will" (Fitzgerald, 2003, p.135) and has not "much self-respect" (Fitzgerald, 2003, p.134). Moreover, Clara points out that, above all these things, Amory "lack of judgment - the judgment to decide at once when you [Amory] know your [his] imagination will play you false, given half a chance" (Fitzgerald, 2003, p.135). Clara observations show that Amory is just egotistic, suggesting excessive love of himself only, and his love, if he has, for Clara is only the way to satisfy him and to fulfill his full of conceit.

Being Clara's husband would mean he can replace her missing husband and save her children. Amory confesses that "I am a slave to my emotions, to my likes, to my hatred of boredom, to most of my desires__" (Fitzgerald, 2003, p. 135), but Clara objects and from her point of view Amory is a slave of his "imagination" (Fitzgerald, 2003, p.135). She refuses Amory and asserts that "I'd never marry again. I've got my two children and I want myself for them" (Fitzgerald, 2003, p. 137). Ironically, we can see once again the image of Beatrice in Clara's appearance; the independent woman wants to devote her life to her son without any help from husband. That's why Clara then reverses her role as Beatrice's when Amory says, "I love you-or adore you-or worship you-" (Fitzgerald, 2003, p. 137). Clara once becomes Amory's mother substitute, and therefore we can say that Amory could never escape his childhood trap in his mind.

The time in Princeton also shows Amory's obsession of adapting himself into the world he wants to fit in. From St. Regis' time, Amory is much self-aware of the importance of sport for gaining popularity and masculinity. Therefore, when he decided to enter Princeton because of its attraction "with its atmosphere of bright colors and its alluring reputation as the pleasant country club in America" (Fitzgerald, 2003, p. 41), Amory also tries to seek for other success that can bring him fame and reputation. At Princeton, Amory learns "to distinguish between upperclassmen and entering men" (Fitzgerald, 2003, p. 43) and he realizes that "now the newest arrivals were taking him for an upperclassman" (Fitzgerald, 2003, p. 43). Amory seems to be adapt to the new world in Princeton, and as the narrator refers, Amory is very proud of himself for "being clever and literacy without effeminacy or affectation" (Fitzgerald, 2003, p. 55). However, it is too early for Amory to have that self-assessment as Fitzgerald right after that depicts Amory's performance as a chorus girl in a musical in Princeton. Surprisingly, Anne Margaret Daniel in her essay titled "Blue as the Sky, Gentlemen" also depicts that Fitzgerald also has experienced as a "Princeton play "Girl" in the Triangle Club show (Fitzgerald, 2003, p. 27). This maybe is the reason why Fitzgerald depicts the performance so skillfully and aptly.

The episode titled "Ha-Ha Hortense!"(Fitzgerald, 2003, p. 58) features a musical comedy performance of the Princeton Triangle Club in which a man dresses up like a woman. The play is given in "a big, barn-like auditorium dotted with boys as girls, boys as pirates, boys as babies"; "how a Triangle show ever got off was a mystery" (Fitzgerald, 2003, p. 59). The performance shows, satirically, the gender reversal inherent in a men's club. Moreover, it seems that Princeton's show encourages the same-sex passion. In this "small society" in Princeton, Amory "now realized only his own inconsequence" and "effort would make him aware of his own impotency and insufficiency" (Fitzgerald, 2003, p. 58). Amory cannot find his true self, his true identity, in this small world in which "the college dreamed on-awake" (Fitzgerald, 2003, p. 58). Van Arsdale's article "Princeton as Modernist's Hermeneutics" also suggests the idea which the Paradise that Amory is trapped in Princeton: "Princeton is itself paradise and the world outside its gate is exile" (Van Arsdale, 2000, p. 41). This claim may be true, generally speaking, but within even this "Paradise", Amory cannot come close to finding a stable sexual identity.

It seems to be an abrupt point when the war reaches America; so Amory and his friends have to say goodbye to Princeton to join the army. The "Interlude: May 1917-February 1919" is short but remarkable and seen as a huge transmission of Amory's life from "egotist" to "personage". Fitzgerald depicts the World War I within the two letters and a short narration. In an essay, "Thoughts for the Times on War and Death" (1915, p. 273-300), Freud puts forth the idea of the disillusionment which the war has evoked, examines altered attitudes towards death and makes various historical observations which are also specifically useful in reading This Side of Paradise. Freud mentions two things in this war which have aroused our sense of disillusionment which are "the low moral standards shown externally by nation states and the brutality shown by individuals" (Freud, 1914, p. 280). It is supposed that the brutality shown by individuals who are supposedly participants in the highest human civilization destroys widely held ideals. People welcome illusions because they spare us unpleasurable feelings, and enable us to enjoy satisfaction instead, but our 
attitudes towards death are far from straightforward. In general, death is considered "natural, undeniable and unavoidable" (Freud, 1915, p. 289).

However, in reality, we are always deeply affected by the occurrence of death. It is a very difficult task to accept that a person we admire has died. Freud says that "in the world of fiction, in literature and in the theatre through compensation" (Freud, 1915, p. 291), we seek for "what has been lost in life" (Freud, 1915, p. 291), and "it is evident that war is bound to sweep away this conventional treatment of death [because] death will no longer be denied; we are forced to believe in it" (Freud, 1915, p. 291). These speculations of Freud can be used to a surprising degree in reading This Side of Paradise, particularly in the steady changes of Amory's feelings towards the deaths of his parents and his friends during the war. Also, we can see the changes of Amory's attitudes towards life and religion after the war.

The first letter in "Interlude" is written by Monsignor Darcy to Amory, who is now "a second lieutenant" (Fitzgerald, 2003, p. 149) stationed in Long Island indicates a very close relationship between them. Darcy himself wishes to become Amory's father as he writes in a letter that "I've enjoyed imagining that you were my son [...] it's the paternal instinct, Amory - celibacy goes deeper than the flesh" (Fitzgerald, 2003, p. 150). Furthermore, Darcy also supposes that Amory is his "reincarnation" (Fitzgerald, 2003, p. 151). Darcy's wish, ironically, fits with Amory's desire to have his own substitute father. However, it is more likely an ominous of Amory's corruption when the war ends because Amory thinks that he will "lead a contemplative, emotionless life" (Fitzgerald, 2003, p. 154). Additionally, Amory, in his letter to his friend, reveals the fact that he no longer believes in Catholic religion as the war has made him only "a passionate agnostic" (Fitzgerald, 2003, p. 153). Amory's emotions depict the fact that the war has a great impact on every individual's life and can change people's concept and personalities. Like Gatsby in The Great Gatsby, Amory has different attitudes toward concept of life and love after the war. However, Gatsby consciously strives to become a mature and wealthy man to pursue his embodied woman but Amory seems to have nothing in his life and does not know exactly what is going to expect him.

Unlike Tender is the Night, Fitzgerald's This Side of Paradise does not emphasize the great trauma that the war bring to us but the intrusive author focus on how the war can change people's perception of life, and similar to what Freud has pointed out, we will seek for what has lost and how we can face with that. Likewise, we can witness Amory's feelings towards death in a letter to a friend at Princeton, now Lieutenant Thomas Parke D'Invilliers. He mentions the deaths of Kerry and Jesse in the war and wonders where Burne is. Amory also concerns his mother's death without any emotions, suggesting only the financial problem he will face after the war. In addition, Amory knows one soldier who "passed through the much-advertised spiritual crisis... I [Amory] honestly think that's all pretty much rot, — though it seems to give sentimental comfort to those at home; and may make fathers and mothers appreciate their children" (Fitzgerald, 2003, p. 153). Amory feels, obviously, great ambivalence in making decisions about life. Late in the novel, only when Amory losses his idealized love, Rosalind Connage, he realizes that the war itself "certainly ruined the old backgrounds, sort of killed individualism out of our generation" (Fitzgerald, 2003, p. 198). Clearly, the war has a great impact on Amory's life and his attitude towards love.

Additionally, Amory idealizes his life based on romantic and Victorian ideals which is clearly illustrated in Book One entitled "The Romantic Egotist". In the early life, Amory himself "had formulated his first philosophy, a code to live by, which, as near as it can be named, was a sort of aristocratic egotistism" (Fitzgerald, 2003, p. 240). Like Anthony in The Beautiful and Damned, Fitzgerald's narrative depicts the desire of a young hero in a quest to shape his identity and masculinity in the world in which Amory believes that a great future will await him. Amory is obsessed by the idea that "I want to be interested", and "I want to be admired" (Fitzgerald, 2003, p. 51). Furthermore, Amory exhibits "the desire to influence people in almost every way, even for evil" (Fitzgerald, 2003, p. 25). For this reason, at St. Regis, Amory strives to be a football star instead of achieving the best marks because he knows it is impossible. Obviously, Amory self-realizes that being a famous football star makes him popularity and reputation. In his first phase of life, Amory is naively self-aware of being gaining fame and popularity in the world. Ironically, the depiction of Amory's desire is in "The Egotist Down" which partly shows his eventual fall in his early life because it just shows Amory is "conceited and arrogant" (Fitzgerald, 2003, p. 33) and never achieves the stable identity.

Not until Amory meets Darcy and confesses that he has "lost half my personality in a year" (Fitzgerald, 2003, p. 100) he once thinks his "personality seemed rather a mental thing, and it was not in his power to turn it on and off like a water faucet" (Fitzgerald, 2003, p. 63) at the age of eighteen. However, Darcy objects and insists that he has "lost a great amount of vanity and that's all" (Fitzgerald, 2003, p. 100), and "we're not personalities, but personages" (Fitzgerald, 2003, p. 101). Darcy then makes a distinction between the two terms "Personalities is a physical matter almost entirely; it lowers the people it acts on [...] But while a personality is active, it over-rides 'the next thing'. Now a personage, on the other hand, gathers" (Fitzgerald, 2003, p. 101). The distinction is somewhat unclear and dim and rather based on Darcy's experiences. However, we can guess that "personalities" are our characteristics that we shape from early life while "personages" allows us to cope with all the rise and fall of life by gathering our experiences and personalities. This conception allows Amory to face and solve various dilemmas "without difficulty" (Fitzgerald, 2003, p. 101). It seems to be the high point of Amory's perception before his life turns into "the education of a personage" period. Therefore, to become coined with a term "personage", Amory "went thoroughly into the destruction of his egotistic highways" (Fitzgerald, 2003, p. 99) to find a way of "classifying and finding a type" (Fitzgerald, 2003, p. 101). Both Amory and Darcy have "a desire to get something definite" beyond mere vanity and so a "personage" is what they 
want to be since Amory wishes to escape from a big shadow of his mother to become an independent man. Unfortunately, on the way to "find a type" Amory gets lost, and cannot identify who he is.

After the war, Amory begins to find an intense romance, trying to replace the miserable incidents in the war. Chapter 1 of Book Two named "The Debutante" depicts the romance between Amory and Rosalind Connage, Alec's sister, which is considered the most important romance and has the greatest impact on Amory's life. We once again see the portrait of Anthony's The Beautiful and Damned and Gatsby's The Great Gatsby reflected through this romance. Rosalind is a beautiful, sophisticated and somewhat has a sexual liberation's viewpoint with "great faith in man as a sex" (Fitzgerald, 2003, p. 160). She dreamily confesses that "I've kissed dozens of men. I suppose I'll kiss dozens more" (Fitzgerald, 2003, p. 165). Ironically, Rosalind and her sister, Cecelia Connage, is also brought up and educated by her unique mother, Mrs. Connage. The narrator gives no hint of Rosalind's paternal role in her family. Nevertheless, Mrs. Connage seems to educate her daughters to become strong and materialistic. Rosalind supposes that "men don't know how to be really angry or really happy-and the ones that do, go to pieces" (Fitzgerald, 2003, p. 162), and "I'm not really feminine" (Fitzgerald, 2003, p. 163). Moreover, Mrs. Connage is much aware of Rosalind's beauty and she thinks it is a weapon to change her life. She tells Rosalind that "you can't do anything without it [money]. This is our last year in this house - and unless things change, Cecelia won't have advantages you've had" (Fitzgerald, 2003, p. 167). Furthermore, Rosalind's mother encourages her to meet "certain men I [Mrs. Connage] want to have you [Rosalind] meet and I don't like finding you in some corner of the conservatory exchanging silliness with anyone" (Fitzgerald, 2003, p. 167). Out of men around Rosalind, Mrs. Connage likes Dawson Ryder most because "he is floating in money" (168). Mrs. Connage symbolizes a power mother figure in the early twentieth century who wants to change all the moral instructions of Victorian time.

But very quickly "within two weeks Amory and Rosalind were deeply and passionately in love" (Fitzgerald, 2003, p. 174). The intense romance makes Amory have "wild dreams of becoming suddenly rich and touring Italy" (1 Fitzgerald, 2003, p. 74). Amory has to take a job at an advertising agency in an attempt to make enough money to satisfy Rosalind. That is the reason Amory self-realizes that he is much more romantic rather sentimental because "sentimental person thinks things will last [while] a romantic person hopes against hope that they won't" (Fitzgerald, 2003, p. 166). Amory idealizes his romance in his way and strives to gain Rosalind's love without realizing that he is going to "break his heart over somebody who doesn't care about him" (Fitzgerald, 2003, p. 171). Amory is always fearful of losing Rosalind as he wishes this romance will last forever for Rosalind now becomes his "life and hope and happiness" (Fitzgerald, 2003, p. 175).

Compared with the previous romances with Myra and Isabelle in which Amory is a person who can control the relationship, this affair with Rosalind only exhibits his out of control and we still witness his weakness and effeminacy. In contrast, Rosalind shows her power and dominant over their relationship. Under her mother's advice and pressure of life, it is inevitably that Rosalind leaves Amory who "hasn't a penny to his name" (Fitzgerald, 2003, p. 178) with "thirty-five dollars a week in advertising" (Fitzgerald, 2003, p. 178) in dark to get married to Dawson Ryder whom she thinks "he's a good man and a strong one" (Fitzgerald, 2003, p. 181). Rosalind thinks that if she marries Amory, she will "ruin both [their] life" (Fitzgerald, 2003, p. 182). Amory really feels lost because it is "the first real unselfishness I've [Amory] ever felt in my life" (Fitzgerald, 2003, p. 181). This romance clearly changes Amory's concept about marriage and family but in a negative romantic point of view. Amory tries in depressed hope but he cannot grasp his love again, "he clenched his teeth so that the tears streamed in a flood from his eyes" (Fitzgerald, 2003, p. 188). Like Dick Diver's Tender Is the Night and Anthony Patch's The Beautiful and Damned, Amory falls into the world of disillusionment and alcohol after the loss of his love. Anthony' "romance is over" (Fitzgerald, 2003, p. 191) when his romantic affair with Rosalind ends. The moral crisis of the war, then losing Rosalind, and having no money, all these facts combine to make him feel lost. Stavola makes it clear when he writes, Amory "finally leaves, once again defeated and deserted by a woman [and] after the affair with Rosalind, Amory undergoes an intense attack of inferiority and identity confusion" (Stavola, 1979, p. 98).

However, Amory's sexual illusion might seem to continue when Amory's “obsession with sex and beauty surfaces again when he is confronted by evil in the form of Eleanor Savage" (Stavola, 1979, p. 98). Stavola exhibits that "Eleanor represents everything Amory has feared and consciously rejected: sex, the unfettered romantic will, materialism, uncontrolled passion" (Stavola, 1979, p. 98). The narrator depicts that Eleanor is a young and wild girl, whom Amory meets on a rainy haystack in Maryland. Then they start an intense romance; however, Amory feels that he is incapable of love from which Stavola suggests that "filled with emptiness and ennui, he [Amory] wants only to drift from one thing to another, make no decisions, no commitments" (Stavola, 1979, p. 99). It can be concluded that Amory once again shows the unstable identity and sexual illusion in his intense relationship and it does depict that Amory seems never to find his identity and inevitably falls into the fantasy world.

\section{CONCLUSION}

This Side of Paradise depicts Amory's sexual illusion throughout his life. Through the time of teenage years to adulthood, Amory repeatedly falls into romantic fantasy which is resulted from the sexual illusion and his unstable identity. From the time he lived with his mother to the years at prep school and Princeton, Amory exhibits characteristic weakness with the loss of his loves and the loss of direction of his father. By using psychoanalytic approach, we can 
come to a much better understanding of the deep-rooted sexual illusion of Amory Blaine, an early representative figure of the Lost Generation. In particular, we can see how Amory's boyhood and the love from his mother, or the lack of role of his father, have affected his later life. Obviously, Amory never escapes from the fantasy world that his mother creates for him and finds his true self.

\section{REFERENCES}

[1] Van Arsdale, N. P. (2000). Princeton as Modernist's Hermeneutics. In J. R. Bryer (Ed.), F. Scott Fitzgerald: New Perspectives. Athens: University of Georgia Press, 39-50.

[2] Bryer, J. R, ed. (2000). F. Scott Fitzgerald: New Perspectives. Athens: University of Georgia Press.

[3] Daniel, A. M. (2000). "Blue as the Sky, Gentlemen". In J. R. Bryer (Ed.), F. Scott Fitzgerald: New Perspectives. Athens: University of Georgia Press, 10-37.

[4] Fitzgerald, F. S. (2003). This Side of Paradise. New York: Scribner.

[5] Freud, S. (2001). The Standard Edition of the Complete Psychological Works of Sigmund Freud, vol. XIV London: Vintage.

[6] James, P. (2005). "History and Masculinity in F. Scott Fitzgerald's This Side of Paradise". Modern Fiction Studies 51.1, 1-33.

[7] Pelzer, L. C. (2000). Student Companion to F. Scott Fitzgerald. Westport, Connecticut: Greenwood Press.

[8] Stavola, T. J. (1979). Scott Fitzgerald: Crisis in an American Identity. London: Vision Press Limited.

[9] Tyson, L. (2006). Critical Theory Today. New York: Routledge.

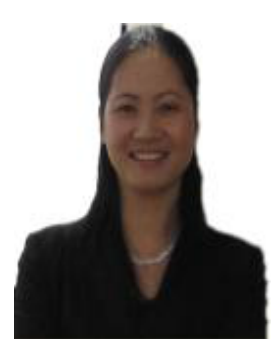

Thi Huong Giang Bui was born in Thai Nguyen, Vietnam in 1980. She studied English and got her B.A. from Thai Nguyen University of Education, Vietnam in 2001. She began working as a teacher of English at Thai Nguyen University of Education, Vietnam in 2001. She continued her Master course in English studies and got her degree from Hanoi University, Vietnam in 2007. She started her Ph.D course in American literature at Fukuoka Women's University, Japan in 2009. She has published some papers in several international peer-reviewed journals. 